\title{
An Outbreak of RSV Infections in the Neonatology Clinic of the University Obstetrics and Gynecology Hospital, Sofia, 2019 - a Case Series
}

Liliya Vakrilova ( $\square$ lilia_vakrilova@mail.bg)

Obstetrics and Gynecology Hospital "Maichin Dom", Medical University of Sofia https://orcid.org/0000-0002-6586-8623

Stanislava Hitrova - Nikolova

Obstetrics and Gynecology Hospital "Maichin dom", Medical University of Sofia

Petya Radulova

Obstetrics and Gynecology Hospital "Maichin dom", Medical University of Sofia

Boryana Slancheva

Obstetrics and Gynecology Hospital of Fudan University

Research

Keywords: RSV-infections, preterm infants, term infants, NICU, Palivisumab

Posted Date: January 11th, 2021

DOI: https://doi.org/10.21203/rs.3.rs-142049/v1

License: (c) (1) This work is licensed under a Creative Commons Attribution 4.0 International License. Read Full License 


\section{Abstract}

Background: Respiratory syncytial virus (RSV) is the predominant cause of lower respiratory tract infections (LRTI) in infancy. Preterm infants with bronchopulmonary dysplasia (BPD) are at the highest risk of severe RSV-LRTI. We report retrospectively a nosocomial outbreak of RSV-infections in the Neonatology of the University O\&G hospital, Sofia.

Methods: Two groups of infants without contact between them were diagnosed with RSV-infection: 14 infants who were treated in the Department for healthy newborns, and 7 preterm infants, treated in the NICU. The detection of RSV was performed using Real-Time PCR in nasal/throat swabs.

Results: Respiratory symptoms occurred 2-5 days after discharge in 14 of 148 healthy term infants born from 5 to 18 February 2019; 12 babies were re-hospitalized with LRTI and recovered in a few days. In 6 infants the RSV-PCR was positive, in the others, RSV etiology was suggested due to similar symptoms and contact between them.

The first NICU-patient with RSV-LRTI was a 26 gestational weeks (GW) twin with BPD. From 19 February to 15 March 26 babies, 26-34 GW at birth were tested for RSV (33 nasal/throat swabs). They received a first or subsequent palivisumab-injection. We identified 11 positive samples in 7 of the babies. Six of them were with symptoms of LRTI, two needed mechanical ventilation. In 4 babies despite the recovery, the second RSV-PCR remained positive. After stabilization 6 babies were discharged home, one was transferred to the Paediatric department for further treatment of BPD.

Conclusions: The reported outbreak of RSV-infections in neonates was the most serious since the RSV-PCR diagnostic in Bulgaria was introduced. The course of RSV-LRTI was severe in extremely preterm newborns with underlying BPD. So routine in-hospital RSV-prophylaxis with palivizumab should be considered for infants at the highest risk.

\section{Background}

Respiratory syncytial virus (RSV) is the most common etiologic agent for acute respiratory infections (ARI) overall and lower respiratory tract infections (LRTI) - bronchiolitis and pneumonia in infants. It has been estimated that RSV causes between 50,000 and 125,000 annual hospitalizations of US children younger than 5 years [1, 2]. In 2015, RSV was responsible for 33.1 million LRT infections worldwide, approximately 3.2 million hospital admissions, and 59,600 in-hospital deaths in children younger than 5 years [3]. RSV is a leading cause of hospitalization in infants less than 2 years of age and can result in serious morbidity and mortality among high-risk groups. [4-6]. Risk factors for more severe disease include premature birth, chronic lung disease (CLD), hemodynamically significant congenital heart disease (CHD), age less than 3 months, neuromuscular disorders, and immunodeficiency [4, 7]. Healthy full-term or near-term infants can be affected too [8]. RSV is mainly transmitted by large particle aerosols or direct contact with contaminated surfaces where the virus can remain virulent for hours. Incubation time is $4-5 d$ with initial viral replication in the nasopharynx; thereafter the virus can spread and cause LRTI. [9]. There is currently no licensed vaccine to prevent RSV infection but passive immunoprophylaxis using a monoclonal antibody, palivizumab, was increasingly implemented in the past 2 decades for high-risk infants following its licensure in 1998. [10,11]. This reduces the risk of RSV-LRTI hospitalization and severe complications in infants predisposed to developing severe RSV disease and specifically for preterm infants with or without CLD and infants with CHD $[12,13]$. RSV was the most frequently detected etiologic agent of LRTI in children under the age of 5 in our country for the seasons 2014/15, 2015/16, 2016/17, 2017/18. [14, 15]. In Bulgaria, prophylaxis with palivizumab in certain risk groups has been applied since 2010 with a gradual extension of the indications in the subsequent years. To date, there are no recommendations in the national guidelines for initiating RSV prophylaxis for at-high risk hospitalized patients.

\section{Materials And Methods}

This is a retrospective case series study that analyzes a nosocomial outbreak of RSV infections in February-March 2019 among inborn infants in the Neonatology clinic of the University Obstetrics and Gynaecology hospital "Maichin doom", Sofia.

Two groups of newborns without contact with each other were affected: Healthy term infants - Group 1; Premature infants who were treated in the Neonatal Intensive Care Unit (NICU) - Group 2. The diagnoses ARI and LRTI were based on standard clinical 
criteria [16]. Clinical information, including demographic characteristics, symptoms, initial diagnosis, and comorbid illnesses, was documented using the hospital case reports for patients. All parents were informed in detail about the disease of the infants and written informed consent for the diagnostics, testing, manipulations, and treatment was obtained. The detection of RSV was performed using Real-Time Polymerase Chain Reaction (PCR). Nasal and pharyngeal specimens were collected and were transported immediately to the National Laboratory "Influenza and Acute Respiratory Diseases" where they were analyzed for viral respiratory pathogens. The primers/probes and protocol used in the study were identical to those described by Kodani et al. [17]. Subgroup-specific primers and probes targeting F and N genes of the RSV were used to determine the RSV-A and RSV-B, respectively using Multiplex Real-Time RT-PCR.

\section{Results}

Group 1: 148 term infants were born and treated in the Department for healthy infants of the Obstetrics and Gynaecology Hospital, Sofia; in the period from 5 to 18 February 2019. Two to 5 days after discharge respiratory symptoms were observed in 14 of them. Twelve babies were hospitalized in different Paediatric Departments in Sofia with symptoms of LRTI (bronchiolitis). Symptomatic treatment was carried out and a few days later after recovery, they were discharged home. There were no complications established for any of these infants. In 4 of the hospitalized babies, as well as in the 2 outpatient infants, the RSVPCR tests from nasal/throat swabs were found positive. In the other 8 hospitalized newborns RSV etiology was suggested due to epidemiological contact between them and the typical LRTI symptoms, but PCR was not performed.

The epidemic outbreak in the NICU (Group 2): In the period from 19 February to 15 March 2019 RSV-infection was established for 7 very low birth weight and extremely low birthweight in-born infants, aged 1-3 months, and treated in the Neonatal Intensive Care Unit (NICU). The data for these patients are summarized in Table 1. 
Table 1

Data and outcome for RSV-PCR positive preterm infants

\begin{tabular}{|c|c|c|c|c|c|c|c|c|c|c|c|c|}
\hline $\mathbf{P}$ & GW & $\begin{array}{l}\text { BW } \\
\text { (g) }\end{array}$ & Sex & D & BPD & $\begin{array}{l}\text { Palivi- } \\
\text { sumab }\end{array}$ & $\begin{array}{l}\text { RSV- } \\
\text { PCR } \\
\text { I }\end{array}$ & $\begin{array}{l}\text { RSV- } \\
\text { PCR } \\
\text { II }\end{array}$ & $\begin{array}{l}\text { RSV } \\
\text { related } \\
\text { symptoms }\end{array}$ & $\begin{array}{l}\text { MV } \\
02\end{array}$ & $\begin{array}{l}\text { Bacterial } \\
\text { Co-infection }\end{array}$ & RSV-outcome \\
\hline 1 & 26 & 1050 & $M$ & 95 & + & 3 & $(+)$ & $(+)$ & $\begin{array}{l}\text { Severe } \\
\text { LRTI } \\
\text { Pneumonia }\end{array}$ & AV & $\begin{array}{l}\text { Enterobacter } \\
\text { cloacae, MRSE } \\
\text { (tracheal probe) }\end{array}$ & $\begin{array}{l}\text { Prolonged } \\
\text { hospitalization }\end{array}$ \\
\hline 2 & 27 & 840 & $M$ & 84 & + & 1 & $(+)$ & $(+)$ & $\begin{array}{l}\text { Severe } \\
\text { LRTI } \\
\text { Pneumonia }\end{array}$ & AV & $\begin{array}{l}\text { Stenotrofomonas } \\
\text { maltofilia } \\
\text { (tracheal probe) }\end{array}$ & $\begin{array}{l}\text { Prolonged } \\
\text { hospitalization }\end{array}$ \\
\hline 3 & 33 & 1410 & M & 46 & - & - & $(+)$ & $\begin{array}{l}\text { No } \\
\text { data }\end{array}$ & $\begin{array}{l}\text { LRTI } \\
\text { (mild) }\end{array}$ & 02 & - & Recovered \\
\hline 4 & 34 & 1410 & $M$ & 23 & - & - & $(+)$ & $(+)$ & $\begin{array}{l}\text { LRTI } \\
\text { (moderate) } \\
\text { Pneumonia }\end{array}$ & 02 & - & Recovered \\
\hline 5 & 31 & 1470 & M & 33 & - & - & $(+)$ & $(+)$ & $\begin{array}{l}\text { LRTI } \\
\text { (moderate) }\end{array}$ & $\mathrm{O} 2$ & - & Recovered \\
\hline 6 & 27 & 1100 & $\mathrm{M}$ & 69 & + & 1 & - & $(+)$ & $\begin{array}{l}\text { LRTI } \\
\text { (moderate) }\end{array}$ & $\mathrm{O} 2$ & - & Recovered \\
\hline 7 & 27 & 850 & $\mathrm{~F}$ & 69 & + & 1 & - & $(+)$ & $\begin{array}{l}\text { No } \\
\text { symptoms }\end{array}$ & - & - & Healthy \\
\hline
\end{tabular}

The first NICU-patient (P1) was a 3 months old male infant, a twin, born at 26 gestational weeks (GW), with a birth weight of $1050 \mathrm{~g}$. The infant had severe bronchopulmonary dysplasia (BPD) but he was already stable and about to be discharged home. The baby had already received three injections of palivizumab from the in-hospital palivizumab-immunoprophylaxis course. At the age of 94 days, there was a rapid deterioration with progressive respiratory failure and symptoms of acute LRTI. The tested nasal and throat swabs were PCR-RSV positive. Due to critical deterioration during the following days, mechanical ventilation was required, including high-frequency oscillations and assisted/controlled ventilation with $100 \%$ oxygen at the beginning. The status of the infant was complicated by superimposed bacterial co-infection - pneumonia. Staphylococcus epidermidis and Enterobacter cloacae were isolated from the probes, taken by bronchial lavage. Antibiotics according to their sensitivity, inhaled corticosteroids (budesonide) and bronchodilators ( $\beta 2$-agonists), cardiotonic treatment, diuretics, an additional (booster) palivizumab injection were administered. There was a slow improvement, the infant was extubated, stabilized, and was transferred to the Paediatric Department for further treatment of the severe BPD. The second RSV-PCR test which was performed at D23 after the onset of the disease remained positive. In summary, RSV infection in this patient significantly deteriorated the clinical course of BPD and delayed discharge home by more than 2 months.

During the period 19 February - 15 March 26 preterm babies, who were treated in the NICU and were in direct (one room) or indirect (medical staff, parents) contact with the first RSV-PCR positive patient, were tested for RSV (33 nasal/throat swabs). All these 26 babies received a prophylactic first or subsequent (booster) dose of palivisumab. We identified 11 positive samples for 7 of the babies with gestational age 26-34 GW, and birthweight 840-1470 g, who were put in isolation (Table 1). In 9 of the samples, RSV-B was typified, in 2 samples typing was not possible. In 4 babies the second RSV-PCR, which was performed from 
1 to 3 weeks after the first sample, remained positive, but the clinical symptoms of LRTI were resolved. Due to respiratory deterioration and contact with each other (twins) 2 babies were re-tested after negative first samples and found to be RSV-PCR positive. In 6 of all 7 RSV (+) premature infants, symptoms of LRTI (bronchiolitis) occurred, 2 of them were with severe respiratory failure and mechanical ventilation was performed, 3 babies were with moderate, 1 with mild symptoms of LRTI, 1 baby (P7, a girl twin) remained asymptomatic. All RSV positive babies were stabilized, 6 of them - discharged home, one was transferred to the Paediatric department, and later discharged too.

For Patient 1 (P1) the clinical RSV-related symptoms and the RSV-PCR positive test occurred after 3 injections of palivizumab, in P2, P6, and P7 - after one injection. These infants were of gestational age 26-27 GW and had underlying BPD, only one of them (the girl) remained without respiratory deterioration. For P3, P4 and P5 palivizumab prophylaxis had not yet been started before the first RSV $(+)$ test. Their gestational age was greater $(31-33 \mathrm{GW})$, they were without BPD and the clinical symptoms of LRTI were mild or moderate.

The following measures have been taken to control the epidemic outbreak:

At the Departement for healthy newborns: intensification of the disinfection regime; restricting visits for relatives other than the mother; denied access for medical staff/parents with respiratory symptoms. As a result of these measures, the epidemic situation was put under control, and after 18.02.2019 there were no new cases with RSV-related respiratory symptoms in full-term infants during the stay in the neonatology ward or following their discharge home.

At the NICU: The RSV-positive patients were isolated from those, who were in contact with them, but asymptomatic until RSVtesting was performed, as well as from those who were not in contact. Palivizumab was administered to all symptomatic and incontact patients (26infants in total): in 22 of them, it was 1st application, in 4-a booster dose.

\section{Discussion}

Here, we describe the first nosocomial RSV-epidemic outbreak in a neonatology clinic in Bulgaria since the introduction of routine RSV-diagnostics by PCR (2013/2014). RSV is the most common viral pathogen in LRTI infections for infants aged less than 5 years of age. According to various authors, RSV causes $50-90 \%$ of hospitalizations due to bronchiolitis, $5-40 \%$ of those due to pneumonia, and 10-30\% due to tracheobronchitis [18-21]. In Bulgaria, for the three seasons - 2015/16, 2016/17, and 2017/18, RSV was identified in $44.5 \%$ of the infants with bronchiolitis and $25.1 \%$ of those with pneumonia [15]. Prevalence of different serotypes during different seasons was established: so during the season of 2014-2015, RSV-A dominated, while over the next three seasons - RSV-B dominated [14, 15]. In all our NICU-samples, where typing was possible, RSV-B was proven. There is a pronounced seasonality of the RSV-infections, which for our country is during December-March with a peak of diseases in February [14, 15], i.e. the epidemic outbreak described here occurred in the second half of the RSV season. The full-term infants affected by the reported outbreak developed LRTI symptoms in the days following discharge home. Twelve of all newborns required short-term re-hospitalization, but the symptoms were resolved quickly and without complications.

In preterm infants, especially those with BPD, RSV-disease is significantly more severe with lower respiratory tract involvement or pneumonia. A bacterial infection is often superimposed, such as in our two most severely affected infants who needed intubation and mechanical ventilation. Infants with higher risk often require re-hospitalization. If the infection occurs in the hospital, discharge is delayed for various periods. In our population of premature babies, this period was between one week for milder cases and over 2 months for the infant with severe underlying BPD and the most severe deterioration. Two infants were returned to mechanical ventilation, for $\mathrm{P} 1$ the condition remained critical for several days. For these two babies, the superimposed ventilator-associated pneumonia caused by Enterobacter cloacae (P1) and Stenotrophomonas maltofilia (P2) further delayed recovery (Table 1$)$.

Following its licensing in 1998 RSV immunoprophylaxis with palivisumab has been implemented in more and more countries with differing reimbursement criteria, which vary over the coming years [10,22, 23]. According to the guidelines of the American Academy of Paediatrics (AAP) until 2014 in many countries RSV immunoprophylaxis was administered to premature infants of gestational age $(G A)<35$ GW $[22,24]$. This has led to a reduction of RSV-hospitalisations for these groups. Several prospective 
clinical trials have demonstrated the efficacy of $45-82 \%$ against RSV-related hospitalizations in high-risk infants $[9,12,13]$. Because palivizumab is very expensive a lot of cost-effectiveness analyses were performed but they do not provide definite recommendations for prophylaxis according to gestational age [25-27]. Furthermore, palivizumab has a half-life of 18-21 days, meaning that monthly injections are required to maintain protective titers during the RSV-season. So in the following years in some countries according to cost-benefit analyses, the reimbursement criteria for Palivizumab prophylaxis were limited to only the most vulnerable infants: those born preterms at $\leq 29$ weeks of gestation; infants with BPD or hemodynamically significant congenital heart disease $[23,24,28]$. The impact of these restrictions on RSV morbidity was controversial. Belleudi, et all. [24] report that in Italy the restricted use of palivizumab following the reimbursement limitations from 2016 was not associated with a significant increase in hospitalization rate for infants of 29-35 g.w. Nevertheless, in 2017 AlFA decided to eliminate the reimbursement restrictions, and recommended palivizumab prophylaxis for infants born at gestational age 30 to $\leq 35 \mathrm{GW}$ and a chronological age $\leq 6$ months at the beginning of the epidemic season [24].

The reimbursement of RSV prophylaxis with palivisumab in Bulgaria has been implemented since 2010, initially covering only the most high-risk group of newborns - those with BPD. In the following years, the criteria were gradually extended to all infants with $\mathrm{GA}<30 \mathrm{GW}$ up to 1 year of age; these $<2$ years of age and requiring treatment for BPD within the previous 6 months, or with hemodynamically significant CHD. Starting season 2019/2020 palivisumab is also reimbursed for preterm infants with gestational age 30 to $<32 \mathrm{GW}$ and $<6$ months at the start of the RSV season. The in-hospital administration of palivisumab is not reimbursed. This means that preterm babies born just before or during the RSV season (December-March for Bulgaria) do not receive passive in-hospital RSV prophylaxis and there is an increased risk of RSV disease. The practice in our NICU is to start offguideline (without reimbursement) palivizumab-prophylaxis at the end of the first month of life for premature infants born in October - December, and with the highest risk of developing BPD and RSV complications respectively. The epidemic outbreak described in this report affected 2 groups of newborn infants without a direct link between them. Of the NICU patients, RSVdisease developed most critically for infants with severe BPD, despite ongoing prophylaxis with Palivisumab. This means that after the first application passive immunity is still insufficient to prevent RSV-disease and that the morphological immaturity of the lung with BPD-related changes contributes to the development of severe RSV-LRTI. In full-term infants, RSV infection occurred as bronchiolitis in the days following discharge home and required short-term hospitalization, or treatment at home, followed by recovery without complications. In these cases, passive immunity provided by transplacental anti-RSV antibodies from the mother would help reduce RSV-disease and hospitalizations in otherwise healthy term or near term newborn infants.

Active immunization of women during pregnancy, for prevention of severe RSV disease during the neonatal period and early infancy, remains a challenge. The suitable vaccination timing during pregnancy, the second or third trimester, is also under discussion. It should be sufficient to ensure the mother develops immunity, maximize transplacental antibody transfer to the fetus, and protection of the newborn, including for those born preterms, who are at increased risk of severe RSV disease, [29]. RSV vaccine research and development activities have increased significantly in recent years [20,30,31]. Several RSV vaccine clinical trials from Phase I to Phase III with a variety of vaccine strategies, summarized by Rezaee, et al, are currently underway or were recently completed but to date, there is no licensed RSV-vaccine for pregnant women [32].

\section{Conclusions}

The reported nosocomial epidemiological outbreak of RSV infections in neonates was the most serious since the RSV-PCR diagnostic in Bulgaria was introduced. It happened during the second half of the local RSV-season. The majority of the affected immature infants had no prophylaxis yet or had received only a single dose of palivizumab before the respiratory symptoms occurred. In extremely premature infants at high risk of developing BPD, born just before or at the beginning of the RSV season, it is appropriate to consider reimbursement of early routine in-hospital RSV prophylaxis with palivisumab to prevent RSV disease, or to reduce its severity and complications.

\section{Abbreviations}

ARI: Acute Respiratory Infections; BPD: BronchoPulmonary Dysplasia; BW: BirthWeight; CHD: Congenital Heart Disease; CLD: Chronic Lung Disease; D: Days; GW: Gestational Weeks at birth; LRTI: Lower Respiratory Tract Infections; MV/O2: Mechanical 
Ventilation/ Oxygen supplementation; NICU: Neonatal Intensive Care Unit; P: Patient; PCR: Polymerase Chain Reaction; RSV: Respiratory Syncytial Virus;

\section{Declarations}

\section{Ethics approval and consent to participate}

This study was conducted by the regulatory standards of Good Clinical Practice and the Declaration of Helsinki. A parent's written informed consent was provided.

The study has been approved by the Local Ethics Committee of the University Obstetrics and Gynecology Hospital "Maichin Dom", Sofia.

\section{Consent for publication}

Not applicable

\section{Availability of data and materials}

The main data analyzed in this study are included in this article. All datasets used and/or analyzed during the current study are available from the corresponding author on reasonable request.

\section{Competing interests}

The authors declare that they have no competing interests.

\section{Funding}

No funding was obtained for this study.

\section{Authors' contributions}

LV researched and interpreted the data, wrote the manuscript, conducted a literature search. SN-H discussed and interpreted the data, edited the manuscript. PR discussed cases and interpreted the data. BS classified and discussed cases, and performed the critical revision of the manuscript.

All authors read and approved the final manuscript.

\section{Acknowledgements}

We thank Prof. Dr. Neli Korsun and Dr. Svetla Angelova (National Laboratory "Influenza and ARD", National Centre of Infectious and Parasitic Diseases (NCIPD), Sofia, Bulgaria) for their collaboration and for the accurate PCR testing of the nasal/throat samples for respiratory viruses which facilitated the diagnosis.

We also thank the NICU medical staff of the University Obstetrics and Gynaecology Hospital "Maichin Dom", Sofia (neonatologists, nurses, technicians) for all efforts in the treatment of high-risk newborns and for the intensive work they have done to overcome the epidemic situation described in the article.

\section{References}

1. Shay DK, Holman RC, Newman RD, Liu LL, Stout JW, Anderson LJ. Bronchiolitis-associated hospitalizations among US children, 1980-1996. JAMA. 1999 Oct 20;282(15):1440-6.

2. Hall CB, Weinberg GA, Iwane MK, Blumkin AK, Edwards KM, Staat MA, Auinger P, Griffin MR, Poehling KA, Erdman D, Grijalva CG, Zhu Y, Szilagyi P. The burden of respiratory syncytial virus infection in young children. N Engl J Med. 2009 Feb 5;360(6):588-98. 
3. Shi T, McAllister DA, O'Brien KL, Simoes EAF, Madhi SA, Gessner BD, et al. Global, regional, and national disease burden estimates of acute lower respiratory infections due to respiratory syncytial virus in young children in 2015: a systematic review and modeling study. Lancet. 2017;390(10098):946-58.

4. Lanari M, Prinelli F, Adorni F, Di Santo S, Vandini S, Silvestri M, Musicco M; Study Group of Italian Society of Neonatology on Risk Factors for RSV Hospitalization. Risk factors for bronchiolitis hospitalization during the first year of life in a multicenter Italian birth cohort. Ital J Pediatr. 2015 May 26;41:40. doi:10.1186/s13052-015-0149-z

5. Bennett MV, McLaurin K, Ambrose C, Lee HC. Population-based trends and underlying risk factors for infant respiratory syncytial virus and bronchiolitis hospitalizations. PLoS One. 2018 Oct 31;13(10):e0205399. doi:

10.1371/journal.pone.0205399.

6. Hall CB, Weinberg GA, Blumkin AK, Edwards KM, Staat MA, Schultz AF, et al. Respiratory syncytial virus-associated hospitalizations among children less than 24 months of age. Pediatrics. 2013 Aug;132(2):e341-8. doi:10.1542/peds.20130303.

7. Blanken MO, Paes B, Anderson EJ, Lanari M, Sheridan-Pereira M, Buchan S, et al. Risk scoring tool to predict respiratory syncytial virus hospitalization in premature infants. Pediatr Pulmonol. 2018 May;53(5):605-12.

8. Blanken MO, Rovers MM, Molenaar JM, Winkler-Seinstra PL, Meijer A, Kimpen JL, Bont L. Dutch RSV Neonatal Network. Respiratory syncytial virus and recurrent wheeze in healthy preterm infants. N Engl J Med. 2013 May 9;368(19):1791-9. Erratum in: N Engl J Med. 2016 Jun 16;374(24):2406.

9. Resch B. Product review on the monoclonal antibody palivizumab for prevention of respiratory syncytial virus infection. Hum Vaccin Immunother. 2017 Sep 2;13(9):2138-49.

10. Palivizumab, a humanized respiratory syncytial virus monoclonal antibody, reduces hospitalization from respiratory syncytial virus infection in high-risk infants. The IMpact-RSV Study Group. Pediatrics. 1998 Sep;102(3 Pt 1):531-7.

11. Torchin H, Rousseau J, Marchand-Martin L, Truffert P, Jarreau PH, Ancel PY. Palivizumab administration in preterm infants in France: EPIPAGE-2 cohort study. Arch Pediatr. 2018;25(2):89-94.

12. Feltes TF, Cabalka AK, Meissner HC, Piazza FM, Carlin DA, Top FH Jr, et al. Cardiac Synagis Study Group. Palivizumab prophylaxis reduces hospitalization due to respiratory syncytial virus in young children with hemodynamically significant congenital heart disease. J Pediatr. 2003 Oct;143(4):532-40.

13. Anderson EJ, Carosone-Link P, Yogev R, Yi J, Simões EAF. Effectiveness of Palivizumab in High-risk Infants and Children: A Propensity Score Weighted Regression Analysis. Pediatr Infect Dis J. 2017;36(8):699-704.

14. Korsun N, Angelova S, Tzotcheva I, Georgieva I, Lazova S, Parina S, Alexiev I, Perenovska P. Prevalence and genetic characterization of respiratory syncytial viruses circulating in Bulgaria during the 2014/15 and 2015/16 winter seasons. Pathog Glob Health. 2017 Oct;111(7):351-61. Epub 2017 Sep 26. PMID: 28948867; PMCID: PMC5694888.

15. Korsun N, Angelova S, Trifonova I, Georgieva I, Voleva S, Tzotcheva I, et al. Viral pathogens associated with acute lower respiratory tract infections in children younger than 5 years of age in Bulgaria. Braz J Microbiol. 2019 Jan;50(1):117-25.

16. Carande EJ, Pollard AJ, Drysdale SB. Management of Respiratory Syncytial Virus Bronchiolitis: 2015 Survey of Members of the European Society for Paediatric Infectious Diseases. Can J Infect Dis Med Microbiol. 2016;2016:9139537. doi:10.1155/2016/9139537.

17. Kodani M, Yang G, Conklin LM, Travis TC, Whitney CG, Anderson LJ, et al. Application of TaqMan low-density arrays for simultaneous detection of multiple respiratory pathogens. J Clin Microbiol. 2011 Jun;49(6):2175-82. Epub 2011 Apr 6. PMID: 21471348; PMCID: PMC3122721.

18. Calvo C, Pozo F, García-García ML, Sanchez M, Lopez-Valero M, Pérez-Breña P, Casas I. Detection of new respiratory viruses in hospitalized infants with bronchiolitis: a three-year prospective study. Acta Paediatr. 2010 Jun;99(6):883-7. Epub 2010 Feb 16. PMID: 20163373; PMCID: PMC7159545.

19. Esposito S, Daleno C, Prunotto G, Scala A, Tagliabue C, Borzani I, et al. Impact of viral infections in children with communityacquired pneumonia: results of a study of 17 respiratory viruses. Influenza Other Respir Viruses. 2013 Jan;7(1):18-26. Epub 2012 Feb 13. PMID: 22329841; PMCID: PMC5780730. 
20. Mazur NI, Martinón-Torres F, Baraldi E, Fauroux B, Greenough A, Heikkinen T, et al. Respiratory Syncytial Virus Network (ReSViNET). Lower respiratory tract infection caused by respiratory syncytial virus: current management and new therapeutics. Lancet Respir Med. 2015 Nov;3(11):888-900. Epub 2015 Sep 25. PMID: 26411809.

21. Centers for Disease Control and Prevention. CDC Data and Statistics: Respiratory Syncytial Virus (RSV). http://www.cdc.gov/rsv/research/ushtml.

22. Committee on Infectious Diseases. From the American Academy of Pediatrics: Policy statements-Modified recommendations for use of palivizumab for prevention of respiratory syncytial virus infections. Pediatrics. 2009;124(6):1694-701.

23. American Academy of Pediatrics Committee on Infectious Diseases; American Academy of Pediatrics Bronchiolitis Guidelines Committee. Updated guidance for palivizumab prophylaxis among infants and young children at increased risk of hospitalization for respiratory syncytial virus infection [published correction appears in Pediatrics. 2014 Dec;134(6):1221. Pediatrics. 2014;134(2):415-20.

24. Belleudi V, Trotta F, Pinnarelli L, Davoli M, Addis A. Neonatal outcomes following new reimbursement limitations on palivizumab in Italy. Arch Dis Child. 2018;103(12):1163-7.

25. Wang D, Bayliss S, Meads C. Palivizumab for immunoprophylaxis of respiratory syncytial virus (RSV) bronchiolitis in highrisk infants and young children: a systematic review and additional economic modeling of subgroup analyses. Health Technol Assess. 2011;15(5):iii-124. doi:10.3310/hta15050.

26. Meissner HC, Kimberlin DW. RSV immunoprophylaxis: does the benefit justify the cost? Pediatrics. 2013;132(5):915-18.

27. Ginsberg GM, Somekh E, Schlesinger Y. Should we use Palivizumab immunoprophylaxis for infants against respiratory syncytial virus? - a cost-utility analysis. Isr J Health Policy Res. 2018;7(1):63. Published 2018 Dec 17. doi:10.1186/s13584018-0258-4

28. Drysdale SB, Green CA, Sande CJ. Best practice in the prevention and management of pediatric respiratory syncytial virus infection. Ther Adv Infect Dis. 2016;3(2):63-71.

29. Saso A, Kampmann B. Vaccination against respiratory syncytial virus in pregnancy: a suitable tool to combat global infant morbidity and mortality?. Lancet Infect Dis. 2016;16(8):e153-e163.

30. Giersing BK, Karron RA, Vekemans J, Kaslow DC, Moorthy VS. Meeting report: WHO consultation on Respiratory Syncytial Virus (RSV) vaccine development, Geneva, 25-26 April 2016. Vaccine. 2019;37(50):7355-62.

31. Vekemans J, Moorthy V, Giersing B, Friede M, Hombach J, Arora N, et al. Respiratory syncytial virus vaccine research and development: World Health Organization technological roadmap and preferred product characteristics. Vaccine. 2019 Nov 28;37(50):7394-5. Epub 2018 Feb 1. PMID: 29395536.

32. Rezaee F, Linfield DT, Harford TJ, Piedimonte G. Ongoing developments in RSV prophylaxis: a clinician's analysis. Curr Opin Virol. 2017;24:70-8. 